\title{
REPRESENTING CORPORATE CULTURE IN CHINA: OFFICIAL, ACADEMIC AND COR
}

Colin Hawes

The China Journal; Jan 2008; 59; Research Library

pg. 33

\section{REPRESENTING CORPORATE CULTURE IN CHINA: OFFICIAL, ACADEMIC AND CORPORATE PERSPECTIVES}

\section{Colin Hawes}

Over the past two decades, and particularly since China entered the World Trade Organization in 2001, there has been an explosion of interest in the concept of “corporate culture" (qiye wenhua 企业文化) among large Chinese corporations. As Table 1 demonstrates, an examination of the websites of the top one hundred Chinese corporations or corporate groups reveals that 75 per cent include corporate culture links on their websites, as do 83 per cent of the top twenty-five privately managed corporations (siying qiye 私营企业). These statistics reveal a strong desire among larger Chinese corporations, whatever their ownership structure happens to be, to publicly represent their interest in "corporate culture". Whether or not these corporations have actually transformed their culturesnamely, their management style, corporate values, work environment and employee behavior-it is striking to find such wide-ranging consensus on the need to publicize or represent their corporate culture to the outside world.

In this paper, I will examine the reasons for this widespread interest in representing corporate culture among large Chinese corporations. The paper is divided into four main sections followed by a conclusion. First, I survey some non-Chinese definitions of corporate culture to show how the concept has been used outside China. Next, I introduce the "official" Chinese representation of corporate culture: how the Chinese government has co-opted this foreign concept, promoted it among Chinese corporations, and in the process re-defined corporate culture to make it a vehicle for the government's own policy priorities. I then compare this "official" representation of corporate culture with "academic" representations, in other words Chinese academic texts. I show that in some cases academics explain and justify the official view of corporate culture and in other cases they strongly reject it. Finally, I demonstrate how five large Chinese corporations publicly represent their cultures, and how they comply with the official requirements for corporate culture - at least on the surface - even when there is no direct legal obligation on them to do so. 
Table 1: Corporate Culture Links on Websites of Top One Hundred Chinese Corporations and Top Twenty-Five Privately Controlled Chinese Corporations $^{1}$

\begin{tabular}{|l|c|c|c|}
\hline & $\begin{array}{l}\text { No. of websites } \\
\text { reviewed (and } \\
\text { currently } \\
\text { functional) }\end{array}$ & $\begin{array}{l}\text { No. of websites } \\
\text { with Corporate } \\
\text { Culture links }\end{array}$ & $\begin{array}{l}\text { Percentage of } \\
\text { total reviewed }\end{array}$ \\
\hline $\begin{array}{l}\text { Top 100 Chinese } \\
\text { Corporations 2006 }\end{array}$ & 95 & 71 & $75 \%$ \\
\hline $\begin{array}{l}\text { Top 25 Privately } \\
\text { Controlled } \\
\text { Corporations 2005 }\end{array}$ & 24 & 20 & $83 \%$ \\
\hline
\end{tabular}

In my conclusion, I argue that the majority of large corporations, including privately managed corporations, appear to be responding to government demands to "improve" their cultures. Of course, one might argue that corporations are simply representing themselves as responding enthusiastically to the government's latest policy priorities, but not necessarily really changing their behavior. ${ }^{2}$ Nevertheless, there are undoubtedly some real impacts involved. Corporations must devote significant budget resources to establishing in-house corporate culture departments and organizing "cultural transformation" activities for their employees. Corporate managers must also work closely with the Communist Party Committees within their corporations-as these Committees are frequently the most enthusiastic proponents of corporate culture change within the firm.

At the same time, it would be misleading to view this as a top-down exercise of political control over corporations by the Chinese government. This is because the Chinese Communist Party (CCP) has itself undergone a transformation in the past decade. It has become much more responsive to the needs of businesses and

1 Source for Top 100 Chinese Corporations 2006 is the Chinese Enterprise Confederation list at: http://www.cec-ceda.org.cn/huodong/2006china500/, accessed 28 November 2007; source for Top 25 Privately-Controlled Corporations 2005 is Private Economy Information Network (Minying jingji xinxiwang) at: http://www.gdcei.com/news_detail.php?id=822\& nowmenuid $=30 \&$ cpath $=0088: \&$ catid $=88$, accessed 28 November $200 \overline{7}$. I confine my focus to Chinese-controlled corporations registered in China. Note that there is some overlap between these two groups, as four of the top 25 privately controlled corporations are large enough to make the top 100 Chinese corporations list. Also, six websites were not functional when the survey was carried out.

2 Having said this, alternative methods commonly used to "reveal" corporate culture - such as interviews, focus groups and site observation - are surely just as dependent on representations by the corporation and its actors as the texts and websites that I rely on for this study. See Barbara Czarniawska-Joerges, Exploring Complex Organizations (London: SAGE, 1992), pp. 17-18; and Narratives in Social Science Research (London: SAGE, 2004), especially Chapters 4 and 8. 
willing to adapt its role within corporations to assist the activities of corporate executives. Likewise, CEOs and employees of large corporations may have their own reasons for embracing certain aspects of the official Chinese definition of corporate culture. Indeed, some corporate executives-even in privately managed corporations - are happy to combine corporate culture programs with Communist-style political indoctrination methods, as they see this leading to a more disciplined and productive workforce. And their rank-and-file employees may not be willing to relinquish certain aspects of the socialist enterprise system either, such as the provision of a range of cultural and educational activities for employees, and the possibility of employee participation in corporations' operational management. I therefore conclude that the corporate culture phenomenon in China is evidence of a pragmatic process of adaptation and accommodation by various corporate stakeholders, including the CCP, corporate managers and employees, and reveals a uniquely Chinese idea of the business corporation, as a hybrid economic-political-cultural organization dedicated to national and individual improvement and renewal.

\section{Non-Chinese Representations of Corporate Culture}

To understand the distinctiveness of Chinese representations of corporate culture, we must first look at how the concept has been applied outside China. Since the early 1980s, a vast amount of literature has appeared on various aspects of corporate and organizational culture. One survey conducted in 1990 revealed 2550 English-language publications with organizational culture or organizational symbolism as key words. ${ }^{3}$ Rather than rashly attempting to deal with this literature comprehensively, I will focus on a selection of books that have been translated into Chinese and which are cited most frequently by Chinese scholars as seminal corporate culture texts. ${ }^{4}$

The promotion of corporate culture as a field of study and a practical management technique took off in the early 1980 s in the United States as a response to the Japanese economic "threat". This is clear from the titles of some early texts on corporate culture, such as William Ouchi's Theory Z: How American Business Can Meet the Japanese Challenge and Pascale and Athos' The Art of Japanese Management. ${ }^{5}$ Even those texts that do not mention Japan in their

3 Martin Parker, Organizational Culture and Identity: Unity and Division at Work (London; Thousand Oaks: SAGE, 2000), p. 59.

4 For example, Chinese Corporate Culture Research Institute (ed.), Qiye wenhua jianming shouce (A Brief Guide to Corporate Culture) (Beijing: Enterprise Management Publishing House, 2002), hereafter Jianming shouce, lists eight English-language texts on corporate culture that it claims led to an "explosion of interest in corporate culture throughout the world" (pp. 3-4). Most of these non-Chinese texts are in the popular "management guru" genre, rather than being rigorous academic studies.

$5 \quad$ William Ouchi, Theory Z: How American Business Can Meet the Japanese Challenge (Reading: Addison-Wesley, 1981); Richard Tanner Pascale and Anthony G. Athos, The 
titles constantly return to the theme that the great success of Japanese corporations (in comparison with struggling US corporations) stemmed from something beyond "scientific" management, econometric analyses, cost curves, and other quantitative or pseudo-rational management techniques, and it was imperative for American corporations to find out what this "something" was. As Deal and Kennedy put it in their highly influential text Corporate Cultures: ${ }^{6}$

A major reason the Japanese have been so successful, we think, is their continuing ability to maintain a very strong and cohesive culture throughout the entire country. Not only do individual businesses have strong cultures, but the links among business, the banking industry and the government are also cultural and also very powerful ... Although this homogenization of values would not fit American culture on a national scale, we do think that it has been very effective for individual companies. In fact, a strong culture has almost always been the driving force behind continuing success in American business.

To provide the basis for a comparison with Chinese representations of corporate culture in the following sections, we should examine in more detail the typical features of corporations with "strong" cultures, as identified in these early American studies.

The first aspect that distinguishes the excellent corporation from its more mediocre peers is its strong set of "shared values", or its "philosophy"? Deal and Kennedy see establishing values as absolutely crucial to the success of corporations: "Shaping and enhancing values can become the most important job a manager can do". These corporate values apparently need not be detailed or complicated. In fact, many of the examples given in the texts are brief slogans focusing on one key aspect such as customer service or quality. ${ }^{9}$ The most important thing is to ensure that the values or philosophy "are a reality in the minds of most people throughout the company, not just the senior executives". ${ }^{10}$ This can be done through techniques such as setting down the values in an

Art of Japanese Management: Applications for American Executives (New York: Simon and Schuster, 1981).

6 Terrence E. Deal and Allen A. Kennedy, Corporate Cultures: The Rites and Rituals of Corporate Life (London; Ringwood: Penguin Books, 1988), p. 5. Cf. Thomas J. Peters and Robert H. Waterman, Jr., In Search of Excellence: Lessons from America's Best-Run Companies (Sydney: Harper \& Row, 1982), pp. 37, 39, 75-76.

7 Thomas J. Peters and Robert H. Waterman, Jr., In Search of Excellence, pp. 76, 279, and Terrence E. Deal and Allen A. Kennedy, Corporate Cultures, p. 23, use the word "values". William Ouchi, Theory Z, Chapter 6, prefers the term "philosophy".

8 Terrence E. Deal and Allen A. Kennedy, Corporate Cultures, p. 22 and Chapter 2.

9 Terrence E. Deal and Allen A. Kennedy, Corporate Cultures, p. 23.

10 Ibid. 
explanatory booklet distributed to all employees, and holding regular sessions where the values are discussed and applied to practical business decisions. ${ }^{11}$

"Successful" corporations often claim that their values stem from the vision and personal example of the firm's founder(s), and so the values are frequently explained and illustrated using "stories" or "myths" about these founders. ${ }^{12}$ Alternatively, the values may be underscored by the behavior of exceptional employees or managers. These individuals then join the ranks of the corporation's role models, or "heroes". Such heroes must be consciously celebrated-and their work publicized-to guide and inspire other employees to embrace the firm's values more enthusiastically. ${ }^{13}$

Another practice that distinguishes the culture of "excellent" corporations is their conscious use of "rites and rituals" to give employees a sense of belonging and give meaning to their work. As Deal and Kennedy put it: "Without expressive events, any culture will die. In the absence of ceremony or ritual, important values have no impact". ${ }^{14}$ Examples of company rituals include: "social rituals", such as regular weekly lunches where senior executives eat with rank-and-file employees in an informal setting; "recognition rituals", such as awards ceremonies where employees learn that their contributions are recognized, even if no monetary rewards are given; "cultural extravaganzas", such as entertainment shows, sports events and motivational speakers; and "management rituals", especially various kinds of meetings where employees and managers can communicate with each other and feel a sense of collective cohesion, even if nothing concrete is actually achieved at these meetings! ${ }^{15}$

Finally, these corporate culture texts invariably assert that successful corporations adapt and continually improve their cultures in response to changes in the external business environment. In other words, cultures are malleable. This means that a "successful" manager (or well-paid management consultant?) should be able to go into any corporation with a negative or "dysfunctional" culture and use the various cultural techniques mentioned above to transform that culture into a positive one that improves employee performance and productivity. All these texts spend significant time on the best ways to "reshape", "change" or "gain control of" the culture within various kinds of organizations. ${ }^{16}$ This whole culture

11 William Ouchi, Theory Z, p. 133.

12 Terrence E. Deal and Allen A. Kennedy, Corporate Cultures, p. 38; Edgar H. Schein, Organizational Culture and Leadership: A Dynamic View (San Francisco: Jossey-Bass, 1985), Chapter 10.

13 Terrence E. Deal and Allen A. Kennedy, Corporate Cultures, Chapter 3; Thomas J. Peters and Robert H. Waterman, Jr., In Search of Excellence, p. 85; William Ouchi, Theory Z, p. 133.

14 Terrence E. Deal and Allen A. Kennedy, Corporate Cultures, p. 63 and Chapter 4.

15 Terrence E. Deal and Allen A. Kennedy, Corporate Cultures, pp. 64-75.

16 See, for example, Terrence E. Deal and Allen A. Kennedy, Corporate Cultures, Chapters 6-9; William Ouchi, Theory Z, Chapters 5-6; Ralph Kilmann, Mary J. Saxton and Roy 
change process is not a sudden one: it is a long-drawn-out struggle that will only show results after several years, possibly even decades. ${ }^{17}$ But the promise is that improving the corporate culture will ultimately lead to better long-term corporate performance.

Of course, since the 1980s many scholars have identified major flaws in the assumptions of these early corporate culture proponents. ${ }^{18}$ Space prevents a detailed appraisal of their criticisms, but for example the claim that cultural factors lay behind the enormous success of Japanese companies is extremely difficult to prove, as various other factors gave Japanese companies a competitive advantage during the post-war period. ${ }^{19}$ Likewise, around one-third of the "excellent companies" identified by Peters and Waterman as having positive cultures failed or experienced severe difficulties soon after their text was published. ${ }^{20}$ Other scholars have attacked corporate culture programs as merely another form of coercion of employees, albeit one where employees are trained to discipline themselves and their peers rather than being constantly watched by their supervisors. ${ }^{21}$ This criticism puts an interesting Marxist spin on the corporate culture debate, and I will return to it in my conclusion, in the light of Chinese attempts to promote "socialist" corporate culture with "Chinese characteristics".

In practice, it is often not at all clear why some corporations succeed when others fail, and experience has shown that changing a company's culture is fraught with difficulties and risks. Yet these risks and complications appear to be lost in the transplantation of corporate culture from the United States into China. As I will demonstrate below, Chinese officials, academics and corporate stakeholders have their own reasons for promoting the corporate culture phenomenon.

Serpa (eds), Gaining Control of the Corporate Culture (San Francisco: Jossey-Bass, 1986), Chapters 12-19.

17 See Harrison M. Trice and Janice M. Beyer, "Using Six Organizational Rites to Change Culture", in Ralph Kilmann, Mary J. Saxton and Roy Serpa (eds), Gaining Control, pp. 370-99, at 371; and William Ouchi, Theory Z, pp. 97, 128-29.

18 Martin Parker, Organizational Culture and Identity, pp. 15-26, gives a good review of criticisms of the corporate culture/performance correlation. For a more positive but still ambivalent perspective, see John P. Kotter and James L. Heskett, Corporate Culture and Performance (New York: Free Press, 1992), especially pp. 141-42.

19 For detailed discussion of the exportation of Japanese industrial management style, see Tony Elger and Chris Smith (eds), Global Japanization: The Transnational Transformation of the Labour Process (London; New York: Routledge, 1994).

20 Martin Parker, Organizational Culture and Identity, pp. 16-17.

21 Martin Parker, Organizational Culture and Identity, pp. 21-23; Gideon Kunda, Engineering Culture: Control and Commitment in a High-Tech Corporation, $2^{\text {nd }}$ edition (Philadelphia: Temple University Press, 2006), p. 11. 


\section{Official Chinese Representations of Corporate Culture}

How do Chinese representations of corporate culture contrast with those we discussed in the previous section? I will focus on two kinds of Chinese texts here, "official" and "academic". "Official" refers to descriptions of corporate culture in policy documents produced by Chinese government bodies, especially the "Guiding Opinion" issued in 2005 by the State-owned Assets Supervision and Administration Commission of the State Council (SASAC). This opinion clearly sets out the Chinese government's prescriptions for corporate culture within the 155 large state-owned corporate groups directly under central government control. "22 "Academic" representations refer to textbooks on corporate culture aimed at university business students and other texts by prominent Chinese experts on corporate culture. There is some overlap between these two categories, as Chinese academics often advise the government on the drafting of corporate policies. Yet at the same time, academic representations generally have more space to explain, justify or reject the prescriptions for corporate culture set out in official policy documents.

Most Chinese texts divide the evolution of corporate culture in China into three stages: ${ }^{23}$

(i) The $1980 \mathrm{~s}$, when bestselling American texts on corporate culture were translated into Chinese, and some Chinese enterprises in coastal regions began experimenting with these new-fangled cultural transformation techniques, but this was not a widespread phenomenon and did not attract the government's attention;

(ii) The post-1993 period, after Deng Xiaoping called for the acceleration of economic reforms and Jiang Zemin encouraged the restructuring of enterprises into corporations, along with a gradual withdrawal of the State from medium and small enterprises. This was the stage when the government started to introduce the term corporate culture (qiye wenhua) into some policy documents, although it was only one of several competing concepts and little attempt was made to apply it in detail, ${ }^{24}$

(iii) The post-WTO period since 2001, when the government stepped up its efforts to reform the larger state-controlled corporations and to try and address some of the abuses that it perceived in privately managed

22 For a description of SASAC's role, see the Commission's website at http://www.sasac. gov.cn/eng/ zrzc.htm, accessed 28 November 2007.

23 See, for example, Jianming shouce, p. 5; Wang Chengrong, Qiye wenhua xue jiaocheng (A Corporate Culture Studies Text) (Beijing: People's University Press, 2003), pp. 7-8; Zhang De (ed.), Qiye wenhua jianshe (Building Corporate Culture) (Beijing: Tsinghua University Press, 2003), p. 286.

24 See, for example, article II.7 of the "Decision on Several Issues Relating to Building a Socialist Market Economic System", approved at the Third Plenum of the Fourteenth CCP Central Committee (14 November 1993). Chinese text available at http://china.com.cn/ch-

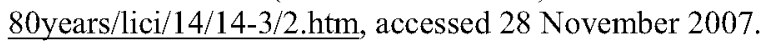


corporations, such as exploitation of employees, asset-stripping and other destructive short-term behavior by owner-managers, and a general lack of international competitiveness among Chinese business corporations. ${ }^{25}$ It also coincided with Jiang Zemin's initiative to welcome successful private entrepreneurs into the CCP in order to neutralize potential opposition from a powerful new capitalist class. ${ }^{26}$ It is at this stage that the government started to view corporate-culture-building as a key transformational technique that could solve many of the problems facing corporations and simultaneously allow the government to exercise more supervision over the privately managed economy.

Thus, although the SASAC document is initially addressed to large corporations controlled by the central government, privately managed corporations are equally targets for the government's corporate culture promotion efforts.

The "Guiding Opinion on Strengthening the Building of Corporate Culture in Centrally Controlled Corporations" (hereafter "Guiding Opinion") was issued by SASAC on 16 March 2005. ${ }^{27}$ It contains eighteen detailed articles arranged under four main sections. Right from article one, an immediate contrast to the nonChinese representations of corporate culture is evident. ${ }^{28}$

Building a progressive corporate culture is a significant factor in strengthening the [Communist] Party's hold on power, in forcefully developing a progressive socialist culture, and in building a harmonious socialist society. It is something that is urgently required to enable enterprises to deepen their reforms, accelerate their development and grow bigger and stronger; it is a necessary choice to allow the Party's dominant political position to flourish, to build a high quality workforce, and to encourage people to develop to their full potential; and it is a strategic move that will enable corporations to improve the quality of their management, strengthen their internal cohesion, and build their core competitiveness.

Though echoes from the American texts, such as improving management quality, strengthening "internal cohesion" and competitiveness, and helping people "develop to their full potential" come through, these benefits are combined with some uniquely Chinese ideas about the relationship between "progressive

25 Zhu Huiye (ed.), Faxian qiye wenhua: qianyan didai (Discovering Corporate Culture: From the Frontlines) (Beijing: Enterprise Management Publishing House, 2003), p. 10.

26 See Bruce Dickson, Red Capitalists in China: The Party, Private Entrepreneurs, and Prospects for Political Change (Cambridge; New York: Cambridge University Press, 2003), pp. 90-92, 101-04.

27 "Guanyu jiaqiang Zhongyang qiye qiye wenhua jianshe de zhidao yijian", issued by SASAC's Propaganda Department. Available on SASAC website at http://www.sasac. gov.cn/gzjg/xcgz/ 200504190137.htm, accessed 28 November 2007.

28 Guiding Opinion, article 1. Unless otherwise indicated, all translations from this source and other Chinese sources below are mine. 
corporate culture" and maintaining the "dominant position" of the Communist Party, strengthening socialism, and building a "harmonious society" ${ }^{29}$

This juxtaposition continues in article five, which states: ${ }^{30}$

With the central focus of improving corporations' competitiveness and economic return, ensuring that state-owned assets are preserved and increased, and promoting the all-round development of employees, corporate-culture-building must be incorporated into the development strategies of firms as a significant component of their operational management. It should be organically integrated with firms' Partybuilding, ideological and political work, and spiritual-civilizationbuilding work.

In a later article, the Party connection is brought out even more forcefully: $:^{31}$

Building a progressive corporate culture is a shared responsibility of corporations' management and Party leaders ... The leadership system for building corporate culture should fit into the modern corporate system and legal person governance structure, and firms' Party Committees, Boards of Directors, and top managers should all be fully involved in the corporate culture strategic development process ... In the process of building corporate culture, firms must pay attention to fully utilizing the grass-roots Party organizations and mass organizations. The broad mass of Party members must play a leading role in this effort, guiding the whole workforce to devote their full efforts to building corporate culture.

The other distinctive feature of the official representation of corporate culture found in the Guiding Opinion is its emphasis on "traditional Chinese culture" and uplifting "cultural activities" as central elements that should be enthusiastically promoted by business corporations. For example, article 12 states: "[Firms] must pay attention to spreading the legacy of the outstanding traditional culture of the Chinese nation". Elsewhere, more detail is given on this duty: ${ }^{32}$

[Firms] must make more effort to provide appropriate cultural resources and to improve corporate culture facilities ... They must use innovative methods for building corporate culture ... especially through new media such as internet sites, in-house corporate publications, broadcasts and cable TV, providing healthy and beneficial cultural products to raise the cultural level of employees and expand the effectiveness of corporate

$29 \mathrm{Hu}$ Jintao called for the building of a "harmonious society" in a speech to the Central Party School in February 2005, following which the concept became part of a new policy emphasis by the government on addressing various social problems and inequities in Chinese society, such as rural unrest and unemployment. For a report on Hu's speech, see "Building harmonious society important task for CPC: President Hu", Xinhua, 20 February 2005, at http://english.people.com.cn/200502/20/eng20050220 174036.html, accessed 28 November 2007.

30 Guiding Opinion, article 5.

31 Guiding Opinion, article 16.

32 Guiding Opinion, article 8. 
culture promotion. They must focus on guiding and strengthening extracurricular group cultural activities such as photography, calligraphy, art, literature and sports, and they must organize a wide variety of healthy and distinctive extracurricular cultural activities in which everyone can participate ... in order to satisfy employees' spiritual and cultural thirst for knowledge, beauty and pleasure.

At the same time, Chinese firms must also be willing to adopt innovative and positive aspects of "progressive" foreign cultures. For example, article 8 declares that firms must "publicize scientific knowledge and widely promote a scientific spirit in order to improve employees' ability to recognize and oppose decadent ideas, feudal superstitions, and fake science". ${ }^{33}$ More broadly, firms must "tightly grasp the progressive aspects of advanced cultures, and with an open, studious, tolerant and synthesizing attitude ... draw inspiration from the excellent cultural achievements of progressive foreign cultures, and courageously imbibe new cultural, ideological and conceptual ideas from all over the world". ${ }^{34}$

So, according to the official view, the ideal corporation is one that can somehow synthesize "progressive" foreign management practices and corporate culture techniques with socialist principles and a healthy dose of traditional Chinese culture, to produce employees who are well-educated and cultivated, loyal Chinese citizens, yet also highly motivated and productive within their firms.

\section{Academic Chinese Representations of Corporate Culture}

As with English-language studies of corporate culture, there is now a vast amount of published Chinese material on this topic. ${ }^{35}$ Among the dozen or so Chinese works on corporate culture reviewed for this study, there is a high degree of overlap in both style and content that I will try to summarize. This does not mean that the views of Chinese corporate culture experts are uniform, however, and some scholars in particular express diametrically opposing views on the appropriate relationship between corporate culture and political/ ideological work within corporations.

Obviously, one major difference between the academic and official representations of corporate culture is in the level of detail provided. Whereas the SASAC Guiding Opinion gives only vague suggestions on implementing corporate culture change strategies, academic texts provide step-by-step accounts of the various kinds of core values, corporate philosophies, rituals, employee incentives, and other techniques that they claim will result in a stronger and more

\footnotetext{
lbid.

Guiding Opinion, article 12.

35 As an indication of the number of publications, the online catalogue at the National Library of China lists 911 books containing qiye wenhua in their titles, of which over 400 have been published since 1999 .
} 
positive corporate culture. The vast majority of these techniques are clearly drawn from the American literature on corporate culture, although Chinese firms that have successfully applied similar methods are also often used as case studies. ${ }^{36}$

Possibly because they have a vested interest in promoting their own field of study and its associated consultancy opportunities, all these academic authors agree that there are clear benefits for firms when they improve their corporate culture. ${ }^{37}$ And like their American models, they tend to ignore the counterarguments raised by subsequent English-language studies that cast doubt on the positive nexus between corporate culture transformation and corporate performance. Yet despite their reliance on imported ideas, all these academic authors take pains to emphasize that Chinese corporations must develop their own distinctive culture that suits the broader Chinese social, political and cultural context. Here emerges further discussion of the two uniquely Chinese aspects of corporate culture that we identified in the official representation above: the relationship between corporate culture and political/ideological work, and the promotion of "Chinese culture" within corporations.

Some academics agree with the official view that Communist Party organizations have an important role to play in building firms' corporate culture. The Tsinghua University text Building Corporate Culture, edited by Zhang De, gives the following justification: ${ }^{38}$

In China, especially in state-controlled corporations, besides economic activities there are also political and cultural activities. Party organizations [and their affiliated] Youth League organizations, Women's Federations and Workers' Unions play a significant role within corporations, and they have enormous impact and influence. They are a powerful resource that should not be overlooked when building corporate culture. If the capabilities of each of these organizations can be fully utilized, then the building of corporate culture will receive widespread support among employees, and this will provide a firm foundation to ensure the success of the corporate-culture-building effort.

Strengthening corporate-culture-building can help to synthesize political and ideological work with corporate management work like a body inhabiting a single skin rather than two separate skins.

36 Most texts summarize the arguments of the seminal American texts that we discussed above. Some also discuss European and Japanese corporate cultures. See, for example, Liu Junxin, Li Jing and Zhang Jianqing (eds), Qiye wenhuaxue (Studies in Corporate Culture) (Tianjin: Tianjin University Press, 2004) pp. 23-36; Wang Chengrong, Qiye wenhua xue jiaocheng, pp. 194-201 and 207-10.

37 See, for example, Wang Chengrong, Qiye wenhua xue jiaocheng, pp. 34-38; Zhang De (ed.), Qiye wenhua jianshe, pp. 29-46; Liu Junxin, Li Jing and Zhang Jianqing (eds), Qiye wenhuaxue, pp. 5-8.

38 Zhang De (ed.), Qiye wenhua jianshe, pp. 281-82. 
Thus Zhang implies that there is considerable overlap between the objectives and content of political work and corporate culture work, and that they naturally complement each other. This optimistic view of the synergy between corporate culture and Party organizational work is not shared by all Chinese scholars:

One of the major tendencies of Chinese corporate culture is to confuse corporate culture work with political and ideological work ... Even though we now have a policy of separating government from enterprise management, and in most state-controlled corporations today, the person in charge is not the Party Secretary but the corporate CEO, still due to historical reasons ... corporate culture work has naturally been made the responsibility of Party organizations ... Now the fundamental objective of corporations is to ... maximize their profits, and this means placing their primary emphasis on economic returns. But Party work places its primary emphasis on political objectives. These two emphases are fundamentally different. If a corporation lists Party political and ideological work as one of the "core values" of its corporate culture, and includes various policies promoted by the government within the definition of its corporate culture, it means that this "corporate culture" will simply not be aligned with the corporation's own developmental requirements ... and this kind of corporate culture will never be accepted by the employees ... To keep political and ideological education as far away from corporations as possible and allow corporations to truly become independent entities guided primarily by their own economic interests - maybe this would be the most direct way to apply the "separation of government from enterprise management"! ${ }^{39}$

Although Ye's argument strongly criticizes the "confusion" of corporate culture with political indoctrination, or even the suggestion that they are linked in any way whatsoever, the very fact that he has to make such an argument indicates that this "synthesis" (in Zhang's terms) is common among Chinese corporate managers. And as I will show below, it is not confined to managers of statecontrolled corporations.

Another distinctive feature of Chinese corporate culture as it appears in the academic literature is the central place awarded to Chinese cultural values and various refined cultural activities designed to cultivate employees. ${ }^{40}$ These texts broaden the term "corporate culture" to include other aspects of culture, such as national culture and élite culture.

39 Ye Sheng, Qiye linghun: qiye wenhua guanli wanquan shouce (The Corporate Soul: A Complete Guide to Corporate Culture Management) (Beijing: China Machine Press, 2004), p. 32.

40 Most texts devote chapters to "Chinese-style corporate culture" or "traditional Chinese cultural values", or contrast Chinese values with American, Japanese and European equivalents. See Wang Chengrong, Qiye wenhua xue jiaocheng, pp. 194-215; Zhang De (ed.), Qiye wenhua jianshe, Chapter 14; Liu Junxin, Li Jing and Zhang Jianqing (eds), Qiye wenhuaxue, Chapters 3-5. 
Two reasons are usually given for this emphasis on Chinese culture. The first is practical necessity. Chinese values are different from "foreign" values, therefore employees will not be properly motivated and the corporation will not operate successfully unless the corporate values are expressed in a way that Chinese employees can naturally relate and respond to. ${ }^{41}$ The second is the superiority of Chinese values. The historical development of Western, especially American, multinational corporations has shown that individualistic and selfish short-term strategies will not produce lasting success. The most successful multinationals have started to embrace a socially responsible corporate citizenship model, where employees are encouraged to develop their talents to the full for the good of the whole corporate group and its surrounding community. These new corporate values are very similar to traditional Chinese cultural ideals, and therefore Chinese corporations should not make the mistake of abandoning their own Chinese values in favor of a short-term Western approach that has already proven to be defective. ${ }^{42}$

Two interesting features recur in these academic accounts of corporate culture and Chinese values. First, they tend to present socialism not as a repudiation of traditional Chinese belief systems such as Confucianism, but as a natural development of them, so that ancient Confucian sayings are cited alongside Marxist and Maoist revolutionary texts as if they are merely differently-worded expressions of the same basic values. Secondly, they reinterpret American corporate culture texts as if they are simply a way of applying Chinese valueswhether Confucian or Maoist-to contemporary problems of corporate management. The result of these various juxtapositions-of ancient and modern, Eastern and Western, capitalist and socialist - is a curiously contradictory vision of the ideal Chinese corporate philosophy.

Consider a quote from the chapter entitled "Chinese Corporate Culture" in the Tianjin University text Studies in Corporate Culture: ${ }^{43}$

China's outstanding traditional culture is a treasure trove from which we should seek inspiration and nourishment in building corporate culture. But we should also reject and discard the damaging aspects of traditional culture. As Mao Zedong put it: ... "We must throw out the feudal dregs

41 Wang Chengrong, Qiye wenhua xue jiaocheng, pp. 215-16; Liu Junxin, Li Jing and Zhang Jianqing (eds), Qiye wenhuaxue, p. 115.

42 Liu Junxin, Li Jing and Zhang Jianqing (eds), Qiye wenhuaxue, p. 146. The "typical Chinese values" identified in the academic literature include: team spirit (or collectivism); putting people first; emphasizing harmony; pragmatism; patriotism; willingness to endure hardship and to struggle to improve oneself; and balancing profit with self-cultivation. See Wang Chengrong, Qiye wenhua xue jiaocheng, pp. 210-12. Cf. Liu Junxin, Li Jing and Zhang Jianqing (eds), Qiye wenhuaxue, Chapter 5; Zhang De (ed.), Qiye wenhua jianshe, pp. 276-77; and for a more critical account of Chinese cultural and political influences, see Ye Sheng, Qiye linghun, pp. 30-34.

43 Liu Junxin, Li Jing and Zhang Jianqing (eds), Qiye wenhuaxue, Chapter 5. 
[of traditional culture] and imbibe its democratic essence: this is a necessary condition for developing a new culture for our nation and raising our nation's self-confidence". ... If Chinese corporate culture loses its basis in the culture of our nation, it will be pale and lifeless.

The authors then discuss several different facets of traditional Chinese cultural values that they believe are especially pertinent for contemporary corporate executives. In a subsection entitled "Self-Discipline and Self-Cultivation", they declare: ${ }^{44}$

Management means using one's own behavior and will to influence others and cause them to follow. "If you are righteous, then others will follow you even without orders; but if you are not righteous, others will refuse to follow you even if you order them to". "If managers want people to trust and accept them, they will receive sincere support and strong cooperation from their colleagues only if they themselves exemplify the moral virtues of straightforwardness, honesty, hard work, respect for others, loyalty, fairness, modesty and frugality ... As the Great Learning puts it: "From the Son of Heaven right down to the common people, everyone should make self-cultivation their first priority". ... Corporate leaders should be like this too: only if they cultivate themselves-watching their words, their actions, and their moral behavior - will they then be able to bring order to families and the nation and peace to the world.

The passages from the "Great Learning" and the Analects were originally meant to describe the "superior person" (junzi), a Confucian ideal-type. Here, however, it is the corporate manager who has to embody these virtues. The authors continue in this vein for several more pages, citing dozens of classical Chinese texts interspersed with Marxist/Maoist exhortations and occasional quotations from Western management gurus. To conclude their point, they juxtapose the wisdom of Confucius with Peter Drucker: ${ }^{46}$

Confucius said: "Those who are virtuous will not be lonely: they will certainly attract followers". ... This is just like the words of that great Master of Management Drucker, who said: "Only those with the ability to manage themselves can become good managers".

Besides emphasizing traditional Chinese values as the bedrock of Chinese corporate culture, many of these academic texts also echo the official view that corporations should encourage their employees to organize and participate in various artistic, cultural and sporting activities. This is because such activities bring employees together in a harmonious way, encourage them to become more

I4 Ibid., pp. 131-32.

45 From Confucius, Analects XIII 6.

46 Liu Junxin, Li Jing and Zhang Jianqing (eds), Qiye wenhuaxue, p. 133, quoting Analects IV 25. The authors do not provide a citation for the Drucker "saying". 
creative-which may inspire innovation in their work-build team spirit, and generally raise their "quality", "cultural level" and "aesthetic sense". ${ }^{47}$ Zhang De's text gives the following list of acceptable employee activities: speech and general knowledge contests (either in English or Chinese); singing competitions (including karaoke); employee variety shows including song and dance, comic sketches and dramas; ballroom dancing; painting, calligraphy and photography contests; group excursions; sports meets (including mountain-climbing, dragon boats and kite-flying); and less strenuous pursuits such as Chinese chess, bridge, card games and mahjong (as long as the corporation ensures that gambling of any kind is prohibited). ${ }^{48}$ In other words, virtually any group activity involving employees seems to be an acceptable manifestation or vehicle for "corporate culture" development.

As with the official representation discussed earlier, there is a strongly moralistic tone in the promotion of these activities that blurs the line between the corporation's interests and broader socio-political agendas. Zhang De notes, apparently without irony, that corporations typically choose speech contest topics like "Welcoming the Olympics to China" and "I love Chinese history", which have little to do with the firm's business but can easily be used to demonstrate its patriotic support of the government's cultural policies. ${ }^{49}$

To sum up, Chinese academic representations of corporate culture on the whole provide further justification for the official views: that corporate culture is beneficial for firms' performance; that it is closely tied up with political and ideological work within corporations-though some academics object to this tendency; and that corporate culture must somehow base itself on or promote "Chinese" culture and values, while simultaneously embracing socialism and accepting the best aspects of foreign cultures and management methods. In the next section of this paper, I examine individual Chinese corporations to see how they present their own corporate cultures, and how they represent themselves as responding to the often self-contradictory definitions of corporate culture emanating from official and academic sources.

\section{Large Chinese Corporations Representing Their Corporate Cultures}

My review of around 125 Chinese corporate websites has shown a large degree of similarity in the ways that large Chinese corporations publicly represent their cultures. To demonstrate that this is not a result of corporations coming from the same industrial sector, ownership type or geographical region, in this section I examine five firms involved in a range of industries situated in different parts of China. I compare a state-controlled corporation situated in Beijing, which one would expect to align itself closely with the official view of corporate culture,

\footnotetext{
47 See Zhang De (ed.), Qiye wenhua jianshe, pp. 186-90.

48 Ibid., pp. 188-89.

49 Ibid., p. 188.
} 
with privately managed corporations of various types situated elsewhere in the country. Obviously the availability of information about these firms' cultures is also a factor, and those that I have selected all provide copious amounts of internal documentary material on their websites (including online magazines, speeches and policy documents, and examples of employees' creative work). In most cases, I have also been able to locate external texts on these firms. The common feature of these five corporations is their listing among the top 300 Chinese corporations by size of assets. ${ }^{50}$

\section{A State-Controlled Corporation: Shougang Group}

Shougang Group (Shougang Jituan) is one of China's major industrial ventures. Since the early-1980s this firm claims to have transformed itself from an insolvent, seriously polluting, inefficient enterprise tainted with corruption and scandal to a profitable, environmental-best-practice steel and hi-tech conglomerate. ${ }^{51}$ Shougang clearly wants outsiders to see it as a model for all that is best about Chinese corporate culture today. Its website declares that in 2005 the Group's central office won an award for being one of the "top ten outstanding national exemplars of corporate culture". The Group has also produced a series of textbooks on corporate culture for use in educating its own and other firms' employees: Shougang's logo is prominently displayed on the covers of these books, and they contain detailed accounts of the Group's management systems and employee motivation methods. ${ }^{52}$

The Group states its corporate "spirit" in the form of a mission statement: "Self-reliant; open; focused on real business results; innovative; trustworthy; and loyal to the firm". ${ }^{53}$ The explanation for "self-reliant" asserts: "We must have a sense of autonomy that does not blame external forces or other people for problems and must rely totally on our own efforts". ${ }^{4}$

The Group presents itself as a good corporate citizen with a deep concern for the environment. Its website declares that "Shougang's constant goal is to

50 Hence my analysis does not draw any conclusions about small or medium-sized corporations.

51 See Shougang's own "Self-introduction" to the Group's development at http://www. shougang.com.cn/companyintro/company/index.html (hereafter "Shougang Self-intro"), accessed 28 November 2007. This summary neglects to mention the major scandal that rocked the Group in the mid-1990s, when its CEO, Zhou Guanwu, was forced to resign after his son, Zhou Beifang, was convicted of bribery and corruption. Several senior Beijing Municipality officials were also implicated including the Mayor, Chen Xitong. See Edward S. Steinfeld, Forging Reform in China: The Fate of State-Owned Industry (Cambridge: Cambridge University Press, 1998), Chapter 6.

52 See http://www.shougang.com.cn/companyintro/culture/22.html, accessed 28 November 2007.

53 See explanation of this slogan (in Chinese) at http://www.shougang.com.cn/companyintro/ culture/1/18.html, accessed 28 November 2007.

54 Ibid. 
harmonize people, technology and the environment, and to work hard towards realizing the balanced and sustainable development of the firm and of the wider society". To this end, the Group claims to have reduced its carbon dioxide and smokestack emissions by 80 per cent over the past ten years. ${ }^{55}$

These kinds of values would not look out of place on an American or Australian corporate website, and most could be justified as relevant to Shougang's business performance, especially as the website also claims that the Group has doubled its earnings in the past five years. ${ }^{56}$ Yet, Shougang's site emphasizes political and ideological concerns as well. For example, the Group's self introduction page notes that it is the Communist Party Committee within Shougang that is responsible for promoting and strengthening the Group's corporate culture. ${ }^{57}$ When Shougang received its 2005 award for exemplifying corporate culture, its Deputy Communist Party Secretary, Jiang Xinghong, also received a national award for being an outstanding "corporate culture management entrepreneur" (whatever that means). ${ }^{58}$ The website clearly states that the company will "deeply study and implement [Jiang Zemin's] important theory of the Three Represents, and will consolidate the building of the [Communist] Party and of spiritual civilization" ${ }^{59}$ The various Party committees and Party study groups that have been established at all levels of the firm have "helped to lead the mass of employees to speed up the reform and development of Shougang", and this is why the Central Organization Department of the CCP in 2001 listed Shougang's Party Committee as a Nationally Progressive Grass-Roots Party Organization ${ }^{60}$ Coming after several paragraphs of Western-style corporatespeak, praising the Group's business restructuring, technological prowess and financial performance, this sudden reversion to Communist-style bureaucratic jargon might seem out of place to a Western corporate executive, but it fits precisely with the official view of corporate culture expressed in the SASAC Guiding Opinion. Likewise with passages on the website that declare Shougang's "total reliance on the mass of employees" and its duty to "protect the rights of the employees to participate in the democratic management of the corporation", not to mention to continuously improve the "ideology and morality" of all its employees. ${ }^{61}$

Shougang's size and proximity to the nation's capital make it particularly visible to the government. Its CEO must therefore strive to make Shougang a

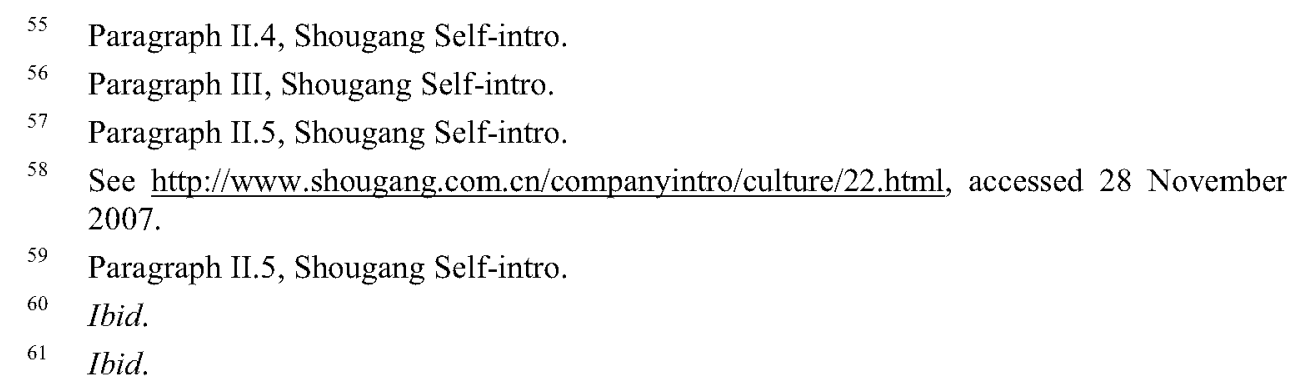


showcase for the Central Government's latest policies or, as the Group's website puts it: "Shougang is situated in the special environment of the nation's capital Beijing ... and we must work for the combined benefit of China, of Beijing Municipality, and of the Corporation and its mass of employees". ${ }^{2}$ As a statecontrolled corporate group, we should also expect Shougang to closely track the requirements in the SASAC Guiding Opinion, especially its emphasis on political and ideological work. But what about corporations of a similar size that are not state-controlled and are situated far away from the nation's capital?

\section{Huawei Technologies: An Employee-Owned Corporation}

One of China's best known employee-owned enterprises, Huawei Technologies Corp. Ltd., is also one of China's most successful hi-tech firms.$^{63}$ Judging by the various values and images presented on its website, Huawei is obviously keen to highlight its international stature and to bolster its reputation as a kind of Chinese version of Cisco Systems. It prominently displays glossy images of its main "campus headquarters" in Guangdong Province, along with numerous publicity shots of its various international operations and research centers around the globe. ${ }^{64}$ The website also constantly reiterates the central importance of providing outstanding customer service throughout its global operation.

Huawei also promotes its cultural values through three monthly magazines available on its website: Huawei People, Huawei Technologies and Huawei Service ${ }^{65}$ One editorial describes Huawei People as "a publication that everyone within Huawei must read; it is not just a source of information; more importantly, it is the frontline for spreading Huawei's culture". ${ }^{66}$ This culture is compared to a wolf:

People all say that Huawei's corporate culture is a "wolf culture". This is because wolves exhibit three tendencies: first, they have a very keen

62 Paragraph II.1, Shougang Self-intro.

63 Though Huawei's ownership structure is rather "murky", it is theoretically an employeeowned corporate group. See Qiu Huihui, "Huawei Jishu yi fenwei si: shangshi zhi lu jiujing hai zou duo yuan?" (Huawei Technologies splits into four: so how long now before it is listed?), 21 Shiji Jingii Baodao (Twenty-First Century Economic Herald) (14 June 2004), p. 1.

64 For Huawei's website, see www.huawei.com/cn/, accessed 28 November 2007. For images of its buildings, see http://market.huawei.com/hwgg/photos/cn/, accessed 28 November 2007.

65 Issues of these e-magazines can be viewed in Chinese at http://www.huawei.com/cn/ publications/PublicationsIndex.do?pid=87, accessed 28 November 2007, and in English at http://www.huawei.com/publications/PublicationsIndex.do?pid=127, accessed 28 November 2007.

${ }^{66}$ My emphasis. See Zhao Jijun, "Ganwu Huawei wenhua" (My sudden realization about Huawei's culture) in Huawei People, No. 164 (10 June 2005) (in Chinese). Posted by its author at: http://www.gunner.net.cn/show.aspx?id=411\&cid=56, accessed 28 November 2007. 
sense of smell; second, they are utterly single-minded in their pursuit of what they want; and third, they have a strong communal spirit. ${ }^{67}$

While the author of this editorial from Huawei People goes on to state that the firm has also adopted various "international business culture" concepts, such as "being led by the customer", "continuous improvement" and "cost consciousness", the primitive image of the wolf remorselessly stalking its prey (the corporation's competitors?) is difficult to shake from the reader's mind. Beneath its glossy cosmopolitan surface, there is certainly something ruthless about the way in which Huawei motivates its employees constantly to raise their productivity. For example, one of the lynchpins of the company's cultural indoctrination is to require all employees to do regular "self criticism"- to reflect publicly on the errors they have made and how they can improve their performance and the effectiveness of the company's products and systems. ${ }^{68}$ The use of the term "self criticism" is a conscious throwback to the chapter devoted to "Criticism and Self-Criticism" in the Quotations from Chairman Mao, more popularly known as the Little Red Book, which states that the "conscientious practice of self-criticism" is essential, because just as "our faces will get dirty if they are not washed regularly", so "our comrades' minds and our Party's work may also collect dust, and need sweeping and washing". ${ }^{69}$ Huawei's CEO, Ren Zhengfei, claims that the company's version of self-criticism is much more "gentle" than that of CCP campaigns. He likens it to "hitting employees a hundred times with a soft pillow". Even if the blows are soft, they will remind employees to keep improving their work. ${ }^{70}$

Every three months, Huawei's different departments and divisions hold a "democratic meeting", and every employee must engage in self-criticism in front of all the other workers. ${ }^{71}$ Managers are included in the process too, and they must also engage in self-criticism in front of their workers. Ren claims that this process

\section{Ibid.}

68 Ibid. More detailed explanation is given in Luo Changhai, Chen Xiaoming, Xiao Chunyan and Guo Canxi (eds), Qiye wenhua jianshe ge'an pingxi (Building Corporate Culture: Critical Analysis of Individual Case Studies) (Beijing: Tsinghua University Press, 2006), pp. 405-27.

69 See Mao Zedong, Quotations from Chairman Mao Tse-tung (Beijing: Foreign Languages Press, 1967), Chapter 27, especially p. 259. Cheng Dongsheng and Liu Lili note in their book Huawei zhenxiang (The Truth about Huawei) that CEO Ren Zhengfei has consciously modeled his leadership style on Mao. See section entitled "Huoxue huoyong Mao Zedong sixiang" (Studying and applying in a new way the thought of Mao Zedong), available online at http://book.sina.com.cn/nzt/1071735627 huawei/index.shtml.

70 Luo Changhai, Chen Xiaoming, Xiao Chunyan and Guo Canxi (eds), Qiye wenhua jianshe ge'an pingxi, p. 413.

71 Ibid., pp. 413-14. Compare Huawei's meetings and self-criticism with the group meetings held in state enterprises during the $1970 \mathrm{~s}$, described in Andrew Walder, Communist Neotraditionalism: Work and Authority in Chinese Industry (Berkeley: University of California Press, 1986), pp. 102-12. 
attacks the Chinese idea of giving "face". In most Chinese companies, to criticize a manager would cause serious loss of face, but if managers don't take public criticism, they will lack any incentive to improve their skills. So Ren insists that managers must publicly criticize themselves. ${ }^{72}$ While this self-criticism procedure is apparently employed with the sole aim of increasing the corporation's performance and profits, the deliberate use of such a politically-charged term shows that Communist techniques of thought control are being reinvented and applied in the new capitalist environment.

Besides this "innovative" use of Communist-era terminology, Huawei also represents itself as active in promoting traditional Chinese culture and other "civilized" cultural activities. Huawei's website contains links to employees' creative writing, galleries of employee photography, and reports of regular "cultural education" classes where employees read and discuss pre-modern Chinese texts, such as the Analects of Confucius and Zen Buddhist parables, as well as non-Chinese "classics" like the Bible and the ubiquitous Peter Drucker. ${ }^{73}$ Huawei also encourages its employees to publish articles for the corporate magazine on their experiences of working for the corporation and their broader reflections on life, awarding annual prizes for the best articles. Though many of these articles are little different from the corporation's own promotional materials, some reveal the ambivalence of Huawei's employees about having to devote their every waking hour to the company, and regret for the loss of a simpler and less stressful life. ${ }^{74}$

\section{Three Privately Managed Corporations: Guanghui, Tianzheng and Guangsha Groups}

Because its ownership structure is not clear, Huawei does not always appear on lists of Chinese "privately managed corporations" (siying qiye). While it appears to be an employee-owned corporation, some commentators suggest that a large proportion of its shares are owned by state-controlled telecommunications providers. ${ }^{75}$ In this final section, I analyze the corporate culture representations of

72 Luo Changhai, Chen Xiaoming, Xiao Chunyan and Guo Canxi (eds), Qive wenhua jianshe ge'an pingxi, p. 414.

73 For employee photography, see http://www.huawei.com/cn/living_at huawei/ colourful life.do, accessed 28 November 2007 ; for creative writing, see $h \mathrm{htp}: / / \mathrm{www}$.huawei.com/cn/ living at huawei/literature.do, accessed 28 November 2007; for cultural education, see Anon., "Chanwu guanli" (Management through Zen Enlightenment), Huawei People, No. 179 (August 2006), at http://www.huawei.com/cn/publications/view.do? $\mathrm{id}=1112$ \&cid= 1222\&pid=87, accessed 28 November 2007.

74 See, for example, Anon., "Memories of Those Nights", Huawei People, No. 176 (June 2006), English version available at: http://www.huawei.com/publications/view.do?id=1041 \&cid=1242\&pid=127, accessed 28 November 2007.

75 See Qiu Huihui, "Huawei Jishu yi fenwei si". For the complexities of corporate ownership in China, see Jean-François Huchet and Xavier Richet, "Between Bureaucracy and Market: Chinese Industrial Groups in Search of New Forms of Corporate Governance", Post-Communist Economies, Vol. 14, No. 2 (June 2002), pp. 169-202. 
three firms that clearly identify themselves as privately managed. These corporations also represent themselves as closely following the government's prescriptions for corporate-culture-building even though the state is not a majority shareholder in their businesses. The three selected companies have all been ranked in the top twenty-five Chinese privately managed corporations by size, but they have operations in different regions of the country. Guanghui Group is a conglomerate based in Xinjiang that focuses on liquefied natural gas production and on automobile trading and servicing. Tianzheng Group (English name Tengen Group) produces various kinds of electrical instruments, and is based in Zhejiang Province (with sales offices throughout China). Finally, Guangsha Group is a construction, tourism, media and educational services conglomerate also based in Zhejiang but with major operations in Shaanxi, Hubei and Shanghai.

While all three of these firms are keen to present themselves as innovative, applying the latest technology, and providing unparalleled service to their customers, they also take great pains to publicize their support of the Communist Party and its policies. The front page of Tianzheng's Chinese website includes a prominently displayed bright red link entitled "Building a Civilized Work Unit", 76 which leads to a whole series of pages on the activities of the firm's Communist Party Committee, including "Party and Mass Work" and "Ideology and Morality". These pages are full of mind-numbingly tedious political jargon on how the company is implementing various Party policies, and their content and style contrast jarringly with the practical business and technology focus of the other links on the site. ${ }^{77}$ Likewise, Guangsha's site proudly declares that it has set up 170 Communist Party branches among its various subsidiaries, and the group was recently praised by the Zhejiang provincial government for being a "progressive grass-roots Party organization". ${ }^{78}$ Guanghui's "Corporate Culture" web page includes links to the Group's Party Organization Building and Communist Youth League activities. The words of Guanghui's corporate song are even set to the well-known revolutionary tune "March of the Chinese People's Liberation Army", 79

76 See http://www.tengen.com.cn/, accessed 28 November 2007.

77 See the page entitled "Wenming chuangjian zhuanlan" (Special Column on Building Civilization), and associated links, at http://www.tengen.com.cn/dj/index.asp?tyid=GBA\& $\underline{\mathrm{lx}=1}$, accessed 28 November 2007.

78 See "Dang zuzhi gaikuang" (Summary of Party Organizations) on Guangsha's website, at http:/www.guangsha.com/gsdj.asp, accessed 28 November 2007. This link also states that Guangsha currently has around 60,000 employees, of whom over 3,000 are Party members, in other words, around 5 per cent of its employees.

79 See "Qiye wenhua" (Corporate Culture), at http://www.guanghui.com/culture/index.asp, accessed 28 November 2007, and for Guanghui's corporate song, see http://www. guanghui.com/culture/whjs/sbxt.asp, accessed 28 November 2007. 
The purposes of all these Party activities are summarized clearly in a chapter about Guangsha from a book entitled The CCP's Grass-Roots Party Building, proudly excerpted on Guangsha's website: ${ }^{80}$

Privately managed corporations are an important component of our nation's socialist economy ... and we should not treat the ownership of corporations as if it is a barrier to building Party organizations. Right from the start, Guangsha realized that the purpose of building Party organizations within a privately managed corporation was ... to strengthen political and ideological work among employees so that they would become more enthusiastic, creative, and willing to take the initiative ... and to strengthen corporate-culture-building to create a firmer motivational foundation for the corporation's development ... Regarding this issue, [Guangsha Group] Chairman Comrade Lou Zhongfu has constantly re-emphasized that Party organizations within privatelymanaged corporations are not subordinate entities neither are they optional extras, so they must be strengthened at every level, right down to units at the grass roots.

Besides displaying their Party credentials as a major aspect of their "corporate cultures", these three privately managed corporations are equally keen to show off their promotion of Chinese culture. It is almost as if they are following the SASAC Guiding Opinion to the letter. Tianzheng, for example, presents the core values of its corporate culture in the form of traditional Chinese ink paintings with calligraphic inscriptions explaining the values in classical Chinese prose ${ }^{81}$ Both Tianzheng and Guangsha produce corporate magazines where employees are encouraged to submit their creative writing and other artistic work for publication. ${ }^{82}$ Likewise, Guanghui has recently set up a series of online forums where employees can display their creativity. ${ }^{83}$ Tianzheng describes its online

80 Central Party School Education and Research Division (ed.), Zhongguo Gongchandang jiceng dangjian (Beijing: Central Party School Publishing House, c. 2006), section on Guangsha posted at http://www.guangsha.com/djcg.asp, accessed 28 November 2007. See also Gu Hailing, "Dangqi zai Guangsha gaoyang" (The Party Flag Flies High over Guangsha), People's Daily, 2 July 2003, posted on Guangsha's website at http://www. guangsha.com/djcgl.asp, accessed 28 November 2007. Interestingly, after the People's Daily article had profusely praised Guangsha's Party building and corporate culture, the Group's Nanjing subsidiary was implicated in a major corruption scandal in 2005, which the subsequent article papers over by praising the Group's Party organization for its rapid response and strict punishment of the managers who were involved.

81 See "Qiye wenhua" (Corporate Culture), at http://www.tengen.com.cn/sm21111111120. asp, accessed 28 November 2007.

82 See Tianzhengren (Tengen People) magazine at http://www.tengen.com.cn/news/tzr/ index.asp, accessed 15 September 2007; and Guangshabao (Guangsha News), described at http://www.guangsha.com/showNews.asp?id=763\&keyword=广厦报, accessed 28 November 2007.

83 See Guanghui's "Hudong zhongxin" (Interactive Centre), at http://www.guanghui.com/ 
magazine Tengen People as "communicating the soul of our employees and displaying our image and spirit. It brings variety to our work lives and is a spiritual harbor, a fragrant meadow of ideas, and a stage to display our talents and wisdom!" ${ }^{84}$ The magazine is produced by Tianzheng's Corporate Culture Development Centre, and the company's CEO Gao Tianle is chair of the magazine's editorial committee ${ }^{85}$ Finally, all three companies organize numerous cultural, sporting and other group activities, which are regularly reported under their "Corporate Culture" web links. Guanghui describes the purposes of these activities as follows: ${ }^{86}$

Through organizing an abundant variety of activities, we will manifest the rich cultural distinctiveness of our corporation, we will strengthen employees' sense of belonging and sense of mission, and we will give full rein to the members of the Communist Party, the Youth League and the Workers' Union to act as exemplary figures and key leaders within the corporation.

As with the official and academic representations of corporate culture, we see in these corporate representations a similar mix of the practical benefits of corporate culture with a heavy dose of political and ideological content, plus a concerted effort to promote Chinese culture and raise the cultural level of employees. These privately managed firms represent themselves as complying as closely as possible with the central government's prescriptions for corporate-culture-building. Indeed, they seem to publicize the role of their Party organizations even more fervently than many state-controlled corporations.

\section{Conclusion}

Why is the Chinese government so concerned about corporate culture-even to the extent of drafting detailed corporate culture provisions for centrally controlled corporations? And just as important, why are corporations, including privately managed corporations, so enthusiastic to embrace the government's reinterpretation of corporate culture, with its emphasis on political indoctrination, promoting Chinese culture and employee cultivation?

The government appears to view corporate culture as a useful political control measure, and has therefore instructed CCP organizations at all levels to implement corporate culture change programs within all corporations that have set up Party committees. However, this explanation ignores much of the content of

interactive/index.asp (which is now password-protected).

84 Introduction to inaugural issue of Tengen People (n.d.), available at http://www.tengen. com.cn/news/tzr/index.asp?bt=第一期, accessed 15 September 2007.

85 See editorial information at http://www.tengen.com.cn/news/tzr/index.asp, accessed 15 September 2007.

86 See "Wenhua huodong" (Cultural Activities), at http://www.guanghui.com/culture/whjs/ whhd.asp, accessed 28 November 2007. 
the official representation of corporate culture: especially that the government also wants to encourage corporations to improve their economic performance and their ability to innovate and apply scientific knowledge. So a more thorough explanation would acknowledge that the CCP has itself undergone a major transformation over the past decade and is looking for a new role to play within Chinese corporations that will assist them in developing their businesses. In particular, since 2001 the CCP has begun to welcome business entrepreneurs, including the CEOs of privately managed corporations, into its ranks, and it now rewards local officials for promoting private enterprise within their regions and thereby helping to increase employment and boost legitimate government tax revenues. ${ }^{87}$ During the 1980 s and 1990 s, the CCP was engaged in a major internal redefinition of itself, recognizing that its own priorities had changed from a political focus on class struggle and creating an egalitarian society to a focus on economic development and raising Chinese peoples' material and cultural standard of living. This new focus culminated in amendments to the Party Constitution in 1997 and 2002 that incorporated the ideas of Deng Xiaoping and Jiang Zemin's Three Represents theory. ${ }^{88}$

In an institutional study of business enterprises in Shanghai conducted during the 1990s, Doug Guthrie concluded that the CCP was stepping back from direct involvement in the management of firms: "At the firm level, although many upper-level managers in factories are Party members, the Party as an organization has no direct role in the decisions and practices the firm adopts ... As general managers and factory directors are increasingly concerned with the firm's economic issues, there is little time or interest in spreading Party ideology within the firm". ${ }^{89}$ It is true that, with the dramatic growth of the privately managed and foreign-invested sectors of China's economy during the $1980 \mathrm{~s}$ and 1990s, the managers of many enterprises that were newly established or restructured from state enterprises either refused to allow the CCP to set up a branch within their firm or effectively sidelined the CCP branch when running their businesses. ${ }^{90}$ However, since the Sixteenth Party Congress in 2002, and particularly after $\mathrm{Hu}$ Jintao and Wen Jiabao came to power, the CCP has made great efforts to expand once again its presence within all forms of business enterprise, including privately

87 Bruce Dickson, Red Capitalists in China, pp. 38-43, 101-04. Cf. Björn Alpermann, "'Wrapped Up in Cotton Wool': Political Integration of Private Entrepreneurs in Rural China", The China Journal, No. 56 (July 2006), pp. 33-60.

88 For the 1997 amendments, see a report on the Fifteenth Party Congress on the website of the CCP at http://english.cpc.people.com.cn/66101/4445269.html, accessed 28 November 2007; for the 2002 amendments, see Xinhua, "Official Explains Amendments to CPC Constitution" (18 November 2002), at http://www.china.org.cn/english/features/49184. $\underline{\mathrm{htm}}$, accessed 28 November 2007.

89 Doug Guthrie, Dragon in a Three-Piece Suit: The Emergence of Capitalism in China (Princeton: Princeton University Press, 1999), pp. 38-39.

90 Bruce Dickson, Red Capitalists in China, pp. 38-42. 
managed and foreign-invested enterprises. ${ }^{91}$ This is reflected in the 2002 Party Constitution by the addition of a new paragraph on the role of the CCP within "non-public economic institutions" where previously only "enterprises owned by the whole people" were mentioned: ${ }^{92}$

In a non-public economic institution, the primary Party organization carries out the Party's principles and policies, provides guidance to and supervises the enterprise in observing the laws and regulations of the state, ... rallies the workers and office staff around it, safeguards the legitimate rights and interests of all stakeholders and stimulates the healthy development of the enterprise.

So on the one hand, the CCP is expanding its presence within business corporations, particularly in privately managed and foreign-invested corporations; on the other hand, the role that the CCP intends to play within those corporations is very different from the pre-reform period because the CCP's "principles and policies" have themselves changed. Economic development is now the top priority, and CCP organizations within firms must therefore subordinate all other work to this central task.

But why should corporations need to host branches of the CCP and its affiliated mass organizations at all? Would it not be more rational and efficient to allow professional managers to run their firms independently, free from any political and ideological considerations, as Ye Sheng argued in his critique of the official representation of corporate culture? This is precisely why the CCP finds the concept of corporate culture so useful, because it allows the CCP to justify its new "business friendly" identity and its continued presence within firms, while at the same time being flexible enough to include the broader cultural and ideological agendas that have been the CCP's bread and butter for decades. According to the official view, corporate culture is an "advanced" idea from abroad that has "proved" its effectiveness in improving the performance and core competitiveness of foreign firms. Therefore, Chinese firms should adopt this idea and implement corporate-culture-building themselves. Yet because Chinese society and culture differ from those of foreign countries, Chinese corporate culture should also reflect those differences - in other words, it should imbibe and promote the values of "Chinese culture". These values appear to be a mixture of traditional Confucian principles, such as the demand for leaders (that is, managers) to be moral exemplars and to cultivate their people (that is, employees); and socialist principles, such as worker participation in firm management and a strong emphasis on the social and political duties of business corporations. Who better to promote this Chinese version of corporate culture

91 See Colin Hawes, "Interpreting the PRC Company Law Through the Lens of Chinese Political Culture and Corporate Culture", UNSW Law Journal, Vol. 13, No. 2 (2007), fortheoming.

92 From Article 32, Party Constitution. Cf. Xinhua, "Official Explains Amendments". 
than the CCP organizations within Chinese firms, since they have such abundant experience of mobilizing employees, enforcing moral norms and organizing educational and cultural activities to improve the "cultural quality" or "spiritual civilization" of the masses?

Therefore, by placing itself at the vanguard of corporate culture reform, the $\mathrm{CCP}$ is carving out a new role for itself within corporations as a kind of socialist corporate culture consultant. It can claim to be reinventing itself, promoting innovative management and helping to improve corporate performance, rather than being a superfluous throwback to the pre-reform state-owned enterprise system. At the same time, the vagueness and flexibility of the definition of corporate culture allows the Party to continue undertaking some of the political and cultural activities that it traditionally promoted in state-owned enterprises, but under a new terminological umbrella. As Geremie Barmé has noted, the CCP has become adept at using the techniques of commercial advertising and public relations to promote itself. ${ }^{93}$ Barmé also identifies a "unique environment" in China of "commodified socialism" or "corporate communism". ${ }^{94}$ I would argue that the enthusiastic embrace of corporate culture by the Chinese government, and its attempt to promote the official view of corporate culture through CCP organizations within all Chinese business enterprises, further demonstrates the transformation of the CCP into a business-friendly institution where economic development is the top priority. In other words, the CCP has itself become a kind of meta-corporation. At the same time, it allows the CCP to claim that it is not neglecting the "social responsibility" of businesses and its own responsibility towards workers and the surrounding community.

If the CCP sees corporate culture as a convenient way of justifying its new role within corporations, what do corporations and their CEOs and employees get from corporate culture? Obviously, by cooperating with the CCP, firms can develop harmonious relations with the government, which may benefit their businesses in various ways. Beyond this, however, are there more direct benefits for corporations themselves in promoting corporate culture? One criticism of corporate culture is that it creates a form of control over employees' minds and behavior. Employees learn to supervise themselves and their fellow employees without having to be told what to do. ${ }^{95}$ This form of "thought control" may be disturbing to corporate outsiders, but it appeals to many corporate managers, including those in China. It also shows interesting parallels with some Maoist-era indoctrination techniques. In other words, corporate culture gives a contemporary Western theoretical justification for managers to adapt Communist mobilization

93 Geremie Barmé, "CCP ${ }^{\mathrm{TM}} \&$ Adcult PRC", The China Journal, No. 41 (January 1999), pp. 1-23.

94 Ibid., pp. 20-23.

95 Martin Parker, Organizational Culture and Identity, p. 23; Gideon Kunda, Engineering Culture, pp. 11, 15-16. 
and thought control techniques to a corporate context, with the aim of improving employee productivity and corporate performance. As a practical matter, Chinese employees may also understand what is required of them more clearly when they hear quotations from Mao Zedong (still widely revered as a national hero in China). In a recent article, Elizabeth Perry suggested that ordinary Chinese citizens have learned to use revolutionary rhetoric and the "language and legacy of the Communist Revolution" to further their own interests. ${ }^{96}$ Many Chinese corporate executives seem to be doing a similar thing when they implement corporate culture change programs using Communist terminology to motivate their employees to work harder. ${ }^{97}$

Looking from the employees' perspective, while it may be true that they must work harder and demonstrate much clearer productivity gains than their predecessors under the state-owned enterprise system, it would be misleading to suggest that they are mere passive cogs in the corporate machine. There is a new job market in China, especially for skilled workers, and the best employees will head for those corporations that provide not only good salaries and training but a range of cultural, educational and sporting activities that help them develop as human beings. ${ }^{98}$ Many large Chinese companies - especially privately managed firms - have grown from virtually nothing in a couple of decades. They have recruited thousands of new employees; most of these are young and come from other parts of the country, and they frequently live in company dormitories or apartments. The company becomes their new home, and they expect the company to arrange such activities so they can get to know their colleagues and feel they are more than just production-line robots. ${ }^{99}$ Of course, the government also has a vested interest in encouraging firms to keep their employees happy, rather than exploiting them, provoking labor disputes and creating social disorder. But to interpret firms' efforts at employee cultivation as purely a top-down control

96 See Elizabeth J. Perry, "Studying Chinese Politics: Farewell to Revolution?", The China Journal, No. 57 (January 2007), pp. 6-7, 17.

97 This has even happened within foreign enterprises in China. Many employees of WalMart China, for example, believe that Sam Walton studied the works of Mao for five years before founding Wal-Mart in the US, and Wal-Mart's "culture" has undergone subtle changes in the translation from English to Chinese that make it more "revolutionary" in expression. See David J. Davies, "Wal-Mao: The Discipline of Corporate Culture and Studying Success at Wal-Mart China", The China Journal, No. 58 (July 2007), pp. 1-27.

98 See Brenda Wilson, "Companies in China Struggling to Retain Staff, Survey Shows", Mercer HR Consulting News Release (30 August 2006), at http://www.mercer.com/ pressrelease/details.jhtml/ dynamic/idContent/1239885, accessed 28 November 2007. This survey found that a major reason for employees selecting a firm was whether it had a "unique organizational culture".

99 David J. Davies, "Wal-Mao", pp. 16-17, notes that the vast majority of Wal-Mart China's workforce are still in their 20s; the same holds true for Chinese firms like Huawei and Tianzheng. 
mechanism would be to underestimate the influence of employees' expectations about how corporations should look after them.

From the resurgence of corporate culture in its unique Chinese guise, perhaps we see a reversion to more traditional view of the "work unit" as a paternalistic environment where managers have a responsibility not only to provide work and material benefits for their employees but to guide them morally and help them to develop their full potential as human beings. ${ }^{100}$ As Davies puts it in his study of the indigenization of Wal-Mart's corporate culture in China: "[Wal-Mart's culture] is formally expressed ... in a moral language and tone in dialogue with Chinese associations of wenhua, or culture, and the historical precedents of state enterprise culture under Mao. Correct practice of corporate culture claims to result in personal transformation and professional success and, at the same time, contribute to Chinese society more generally". ${ }^{01}$

Guthrie concluded his study of the emergence of capitalism in China with the following observation: "Firms' networks, the institutional and political environments in which the firms are embedded, and the historical legacies of institutions all matter for the decisions and practices economic actors adopt in periods of upheaval and reform". ${ }^{102}$ This may be true as a general proposition, yet Guthrie also argues that there has been a "fundamental shift" in China from what he called "socialist management style" to a more modern, Western-influenced "formal rational management style where authority is less particularistic, more impersonal, more dependant on formalized institutions". ${ }^{103}$ As evidence of this "shift", he identifies the increasing use of "organizational rules, job descriptions, grievance-filing procedures, mediation committees, workers' representative committees, promotion tests, and formal hiring procedures", all of which "constitute the firm-level structures of these emerging formal rational bureaucratic systems". ${ }^{104}$ It may be that Guthrie was writing before the most recent reassertion by the $\mathrm{CCP}$ of its right to build a strong presence within business corporations of all types, and before the official promotion of corporate culture began strongly to influence the self-representation of Chinese firms. But the evidence now clearly suggests that his conclusions are premature, and that earlier patterns of authority are finding a way to reassert themselves, even if through new and "foreign-sounding" business terminology. Nevertheless, this does not mean a "return" to "socialist management". As early as the 1980s, Walder noted the phenomenon of ${ }^{105}$

\footnotetext{
100 Andrew Walder, Communist Neotraditionalism, Chapter 1.

101 David J. Davies, "Wal-Mao", p. 3.

102 Doug Guthrie, Dragon in a Three-Piece Suit, p. 205.

103 Ibid., p. 60.

104 Ibid., p. 71.

105 Andrew Walder, Communist Neotraditionalism, p. 239.
} 
... a growing de-politicization, or de-ideologization, of the management of factories and of the Party's self-definition; and a corresponding emphasis on tacit consent to Party authority rather than active ideological commitment ... The current paternalistic approach mixes ... demands for obedience and an emphasis on loyalty (as reflected in job performance and voluntary work) with elaborate displays of concern over workers' material life.

This description of the "current paternalistic approach" would fit comfortably within the official definition of corporate culture found in the SASAC Guiding Opinion. Walder called this approach "a new version of the generic communist pattern, not its erosion". ${ }^{106}$ But with Davies, I would dig even deeper into the historical past than Walder. This pattern is evident even within the preCommunist ancestors of today's business corporations. In other words, the emergence of a unique Chinese representation of "corporate culture" should not be surprising in a society where "culture" has for centuries been intimately associated with national renewal and moral cultivation, and where the "work unit" has been viewed as a place where culture and work are united. ${ }^{107}$

I see the corporate culture phenomenon in China as a pragmatic process of adaptation and accommodation by various corporate stakeholders, including the $\mathrm{CCP}$, corporate managers and employees, through which the non-Chinese concept of corporate culture has been reinterpreted to fit into the Chinese political, social and business context - a context that has itself undergone dramatic changes in the past three decades. In the process, a more traditional Chinese idea of the business corporation, as a hybrid economic-political-cultural organization dedicated to national and individual improvement and renewal, has reasserted itself.

\footnotetext{
106 Ibid., p. 241.

107 David J. Davies, “Wal-Mao", pp. 5-6.
} 